УДК 636.32/38:677.31:577.1

\title{
COMPARATIVE CHARACTERISTICS OF INTERNAL LIPIDS IN WOOL FIBRES OF DIFFERENT TYPES
}

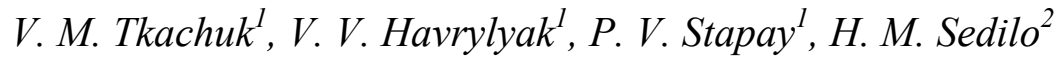 \\ havvita@ukr.net
}

\author{
${ }^{1}$ Institute of Animal Biology NAAS, V. Stus str., 38, Lviv, 79034, Ukraine \\ ${ }^{2}$ Institute of Agriculture of Carpathian region, Hrushevskoho str., \\ Obroshyno village, Lviv region, 81115, Ukraine
}

The paper presents the investigation of the content and composition of internal lipids and protein fractions - keratoses in the different types of wool fibers. These data may be some of interest to the textile industry. For experiment the samples of fibers from Askanian fine-fleece, Askanian crossbred and Carpathian Mountain ewes were used. Semi-course fibers of Carpathian Mountain ewes also were divided into fuzz and guard hair.

It was established that different wool fibers contain various amounts of structural lipids: free internal lipid fraction are rising with increasing of the fiber diameter and opposite dependence for covalently bound lipids is observed. In general, the total content of free and bound lipids in the different fibers is almost identical: thin fuzz contains $2.6 \%$, and fine, crossbred and semicourse wool - 2.65\%, 2.60\% and $2.85 \%$ respectively.

The differences in the structural lipids content are associated with the fiber structure in particular $\alpha$-, $\beta$-, $\gamma$-keratoses. The largest amount of $\beta$-keratose in semi-coarse wool can be associated with the highest content of nonidentified lipids, which are not found in the free fraction of structural lipids.

A correlation analysis between the content and composition of structural lipids and protein fractions wool fibers was performed.

It was found a direct relationship between the content of free lipid fraction and fiber diameter $(r=0.996 ; 0.887 ; 0.698 ; 0.746$, respectively, for fuzz, thin, crossbred and semi-course wool). The inverse relationship for covalently bound lipids were observed $(r=-0.993 ;-0.995 ;-0,737 ;-$ 0.694).

Keywords: WOOL FIBER, DIAMETER, FREE AND BOUND INTERNAL LIPIDS, $\alpha-, \beta-\gamma$-KERATOSES, CORRELATION

\section{ПОРІВНЯЛЬНА ХАРАКТЕРИСТИКА ВМІСТУ І СКЛАДУ СТРУКТУРНИХ ЛІПІДІВ У РІЗНИХ ТИПАХ ВОВНЯНИХ ВОЛОКОН}

\author{
В. М. Ткачук ${ }^{1}$, В. В. Гавриляк ${ }^{1}$, П. В. Стапайㄱ, Г. М. Седіло ${ }^{2}$ \\ havvita@ukr.net
}

\begin{abstract}
${ }^{1}$ Інститут біології тварин НААН, Україна, м. Львів, 79034, вул. В. Стуса, 38
${ }^{2}$ Інститут сільського господарства Карпатського регіону НААН, Україна, Львівська обл., с. Оброшино, вул. Грушевського, 81115
\end{abstract}

У статті представлено результати дослідження вмісту та складу структурних ліпідів, а також протеїнових фракиій кератоз у різних типах вовняних волокон, щуо може становити певний інтерес для текстильної промисловості.

Для дослідження використовували зразки вовняних волокон від вівцематок асканійської тонкорунної, асканійської кросбредної та гірськокарпатської порід. Напівгрубі вовняні волокна гірськокарпатських вівцематок розділяли на тонкий пух та товсту ocmb.

Встановлено, щчо різні категорії вовняних волокон містять різну кількість загальних ліпідів: вміст вільних структурних ліпідів підвишується із збільшенням діаметра волокна, а для фракції ковалентно зв'язаних The Animal Biology, 2013, vol. 15, no. 2 
ліпідів спостерігається діаметрально протилежна залежність. У сумі загальна кількість вільних $i$ зв'язаних ліпідів у різних вовняних волокнах є майже однаковою: тонкий nух містить 2,6\%, а тонка, кросбредна $i$ напівгруба вовна - відповідно 2,65; 2,60 i $2,85 \%$.

Різниці у вмісті структурних ліпідів пов'язані з особливостями структурної будови вовняних волокон різної тонини, а саме із різним вмістом $\alpha$-, $\beta$ - $i$-кератоз. Найбільша кількість $\beta$-кератози зумовлена найвищим вмістом неідентифікованої фракиії у складі зв'язаних ліпідів, яких не виявлено у складі вільної структурних ліпідів.
Проведено корелячійний аналіз між вмістом та складом структурних ліпідів $i$ протеїновими фракціями вовняних волокон.

Встановлено пряму залежність між вмістом фракиї вільних ліпідів та діаметром волокна ( $r=0,996 ; 0,887 ; 0,698 ; 0,746$ відповідно для пуху, тонкої, кросбредної та напівгрубої вовни) та обернену залежність між тониною вовни і вмістом ковалентно зв'язаних ліпідів $(r=-0,993 ;-0,995 ;-0,737 ;-0,694)$.

Ключові слова: ВОВНЯНЕ ВОЛОКНО, ДІАМЕТР, ВІЛЬНІ ТА ЗВ'ЯЗАНІ СТРУКТУРНІ ЛІПІДИ, $\alpha-, \beta-, \gamma-$ КЕРАТОЗИ, КОРЕЛЯЦІЯ

\title{
СРАВНИТЕЛЬНАЯ ХАРАКТЕРИСТИКА СОДЕРЖАНИЯ И СОСТАВА СТРУКТУРНЫХ ЛИПИДОВ В РАЗЛИЧНЫХ ТИПАХ ШЕРСТНОГО ВОЛОКНА
}

\author{
В. М. Ткачук ${ }^{1}$ В. В. Гавриляк ${ }^{1}$, П. В. Стапай', Г. М. Седило \\ havvita@ukr.net
}

\author{
${ }^{1}$ Институт биологии животных НААН, Украина, г. Львов, ул. В. Стуса, 38, \\ г. Львов 79034 \\ ${ }^{2}$ Институт сельского хозяйства Карпатского региона НААН, Украина, Львовская обл., \\ с. Оброшино, ул. Грушевского, 81115
}

B cтатье представлены результаты исследования содержания и состава структурных липидов, а также протеиновых фракций - кератоз, в различных типах шерстных волокон, которые могут представлять определенный интерес для текстильной промышиенности.

Для исследования использовали образцьь шерстных волокон от овиематок асканийской тонкорунной, асканийской кроссбредной $u$ горнокарпатской пород. Полугрубые шерстные волокна горнокарпатских овцематок разделяли на тонкий пух и толстую ость.

Установлено, что различные категории шерстных волокон содержат разное количество общих липидов: содержание свободных структурных липидов повылиается c увеличением диаметра волокна, а для фракции ковалентно связанных липидов наблюдается диаметрально противоположная зависимость. В сумме общее количество свободных и связанных липидов в различных шерстных волокнах является почти одинаковым: тонкий пух содержит 2,6\%, а тонкая, кроссбредная и полугрубая шерсть соответственно 2,65, 2,60 и 2,85\%.
Отличия в содержании структурных липидов связаны с особенностями строения шерстяных волокон различной тонкости, а именно с разным содержанием $\alpha-, \beta-u \quad \gamma-$ кератоз. Наибольшее количество $\beta$-кератозы обусловлено высоким содержанием неидентифищированной фракции в составе связанных липидов, которых мы не обнаружили в составе свободных структурных липидов.

Проведен корреляционный анализ между содержанием и составом структурных липидов $и$ протеиновыми фракциями шерстяных волокон.

Установлена прямая зависимость между содержанием фракции свободньх липидов и диаметром волокна ( $r=0,996 ; 0,887$; 0,698; 0,746 соответственно для пуха, тонкой, кроссбредной $u$ полугрубой шерсти) $u$ обратную зависимость между тониной шерсти и содержанием ковалентно связанных липидов ( $r=-0,993 ;-0,995 ;-0,737 ;-0,694)$.

Ключевые слова: ШЕРСТНОЕ ВОЛОКНО, ДИАМЕТР, СВОБОДНЫЕ И СВЯЗАННЫЕ СТРУКТУРНЫЕ ЛИПИДЫ, $\alpha-, \beta-, \gamma$-КЕРАТОЗЫ, КОРРЕЛЯЦИЯ 
Despite the significant application of synthetic fibers, goods from natural fibers are always in stable demand. Among all animal fibers wool is the most commercially attractive. Wool is characterized by high hygiene, physical, mechanical and technological properties. The process of wool dyeing, as well as various operations against shrinkage, felting etc. is closely related to the structural composition and chemical properties of fibers, including modification of their surface [1].

Wool fiber consists of keratin and small amount (about $3 \%$ ) of lipids called structural or internal. Some of these lipids are in a free state and another part is covalently bound through anteisobranched 18methyleicosanoic acid.

Internal lipids are structured as lipid bilayers in the cell membrane complex (CMC) and make a large contribution to diffusion, cell cohesion, and mechanical strength. The loss of these lipids could impair the integrity of the hair, leading to deterioration in its tensile properties [2].

Therefore, taking into account the fundamental role of structural lipids in formation of technological characteristics of wool fibers, the aim of our study was to compare the content and composition of internal lipids and protein fractions keratoses in different types of wool fibers, which may be some of interest to the textile industry. These data also broaden our knowledge related to the role of structural lipids in the different type of wool fibers.

\section{Material and methods}

Raw wool fiber samples from ewes of three different breed were used in experiment:

- the fibres of Askanian finefleece ewes with mean diameter $20.4 \mu \mathrm{m}$;

- the fibres of Askanian crossbred ewes with mean diameter $30.6 \mu \mathrm{m}$;

- wool samples from semi-course Ukrainian Carpathian Mountain ewes were separated into two morphological types fuzz (mean diameter $16.9 \mu \mathrm{m}$ ) and guard hair (mean diameter $48.8 \mu \mathrm{m}$ ).
All wool fibers were obtained after spring shearing.

Prior to the extraction wool fibers were prepared in the laboratory as follows: wool was washed with neutral detergent solution, washed five times with the warm water and twice with the distilled water, then dried at the room temperature and subsequently cleaned in order to remove all the contaminants. Surface lipids were extracted in the Soxhlet apparatus with carbon tetrachloride for 6 hours.

Extraction of free internal lipids The internal free lipids were extracted from wool ( $3 \mathrm{~g}$ ) in the Soxhlet apparatus for 5 hours using a mixture of chloroform/methanol $(2: 1, \mathrm{v} / \mathrm{v})$. The lipid extracts were collected, evaporated to dryness and then weighed on an analytical balance.

Extraction of bound internal lipids. The extraction of bound internal lipid was performed as described [3]. For this purpose, wool samples after removal of free internal lipids were subjected to alkaline hydrolysis by heating for $2 \mathrm{hr}$ at $60^{\circ} \mathrm{C}$ with $1 \mathrm{M} \mathrm{KOH}$ in $90 \%$ $\mathrm{CH}_{3} \mathrm{OH}$. Then the samples were cooled to room temperature and transferred to the separatory funnel, where $100 \mathrm{ml}$ of chloroform and $25 \mathrm{ml}$ of distilled water were added. After 12 hours the lower chloroform layer was taken to the flask and the upper phase including fiber residue was acidified by the addition $50 \mathrm{ml}$ of $6 \mathrm{M} \mathrm{HCl}$. Then acidified upper phase was mixed with $100 \mathrm{ml}$ of chloroform. Further, the combined chloroform extracts were mixed, filtered and dried by evaporation. The precipitates were dissolved in $10 \mathrm{ml}$ mixture of chloroform-methanol $(2: 1, \mathrm{v} / \mathrm{v})$ and $2 \mathrm{M} \mathrm{KCl}$ containing $0.1 \mathrm{M} \mathrm{HCl}$ was added to each sample. After 24 hours upper phase containing hydrophobic peptides was removed by water pump and lower phase, which contained the lipids was filtered and dried in glass tube. The weight of lipids was then determined.

For the analysis the covalently bound internal lipids which are extracted after alkali saponification were used.

The lipid extract was re-dissolved in the chloroform/methanol mixture. The thinlayer chromatography was carried out on $0.11 \mathrm{~mm}$ thick layer of silica gel STH-1A 
(Sorbfil, «Sorbpolymer», Krasnodar, Russia) on $10 \times 10 \mathrm{~cm}$ polyethylen-tereftalat plates. Samples were applied $1 \mathrm{~cm}$ from the bottom edge of the plate. Chromatographic separation of internal lipids was carried out in two systems: petroleum ether/diethyl ether (4:1, $\mathrm{v} / \mathrm{v})$ and chloroform/methanol/water (65:25:4, $\mathrm{v} / \mathrm{v})$. After drying, the chromatograms are sprayed with $50 \%$ sulfuric acid and charred at $105^{\circ} \mathrm{C}$. Cholesterol, cholesterol sulfate, stearic acid, lanosteryn (Sigma Chemical Co., St. Louis, USA) was used as standards.

To quantify the concentration of lipid classes the spots were scraped, transferred to a glass tube, where were added concentrated sulfuric acid and heated to a temperature of $105{ }^{\circ} \mathrm{C}$. Absorbance of each fraction was determined photocolorimetrically at a wavelength of $400 \mathrm{~nm}$ in cuvette of $1 \mathrm{~cm}$ thickness. Other classes of lipids compared with $r_{\mathrm{f}}$-values of lipid classes according to literature data $[3,4]$.

Keratoses analysis. Fractionation of wool into the keratoses was performed as described in [5]. Wool samples were oxidized with performic acid for $16 \mathrm{hr}$ at $0{ }^{\circ} \mathrm{C}$. Oxidized wool was transferred to flacks with $1.5 \mathrm{M}$ ammonia solution and mixtures allowed to stand for $30 \mathrm{hr}$. The residues of $\beta$-keratose were filtered, washed with water and dried to constant weight at $105{ }^{\circ} \mathrm{C}$. Liquor of performic acid and water washings were collected to a total volume of $100 \mathrm{ml}$ and glacial acetic acid was added to $\mathrm{pH}$ 4.0. The $\alpha$-keratose precipitates were allowed to coagulate during $24 \mathrm{hr}$ and filtered. Then $\alpha$-keratose were washed, dried and weighted. Results were expressed as percent of the weight of the oxidized wool and $\gamma$-keratose were differences from $100 \%$.

Statistical analysis. Statistical evaluation of results was conducted using the arithmetic mean and standard error $(M \pm m)$ and the adequate interval for assessing the degree of probability (P) using Student's criterion $(\mathrm{t})$.

Differences were statistically significant at $\mathrm{P}<0.05$.

\section{Results and discussion}

Wool is a multifunctional fiber with a different diameter that makes it suitable for clothing, household fabrics and technical textile. Changes of lipid composition related to various damage of hair are well known, but limited data are available on variation within different categories of wool fibers.

Results of the comparison of total content of structural lipids in various categories of wool fibers are illustrated in figure



Fig. 1. The total lipids content of fuzz, fine wool, crossbred wool and guard hair 
Analyses of the overall content of structural lipids among different fibers shows that the sum of both free and bound fractions in all fibers is identical. But the smallest content of free internal lipids are in thin fuzz $(0.75 \%)$ and the largest amount is observed in guard fibers $(1.39 \%)$. Inversely relationship for bound lipids is found.
The major lipid classes separated in system petroleum ether: diethyl ether $(4: 1, \mathrm{v} / \mathrm{v})$ were cholesterol ester, free fatty acids, fatty alcohols and cholesterol as shown in figures $2-3$. In the present study it is shown that cholesterol is the dominant fraction of the free internal lipids, and cholesterol esters are the predominant fraction of the covalently bound lipids of all wool fibers.

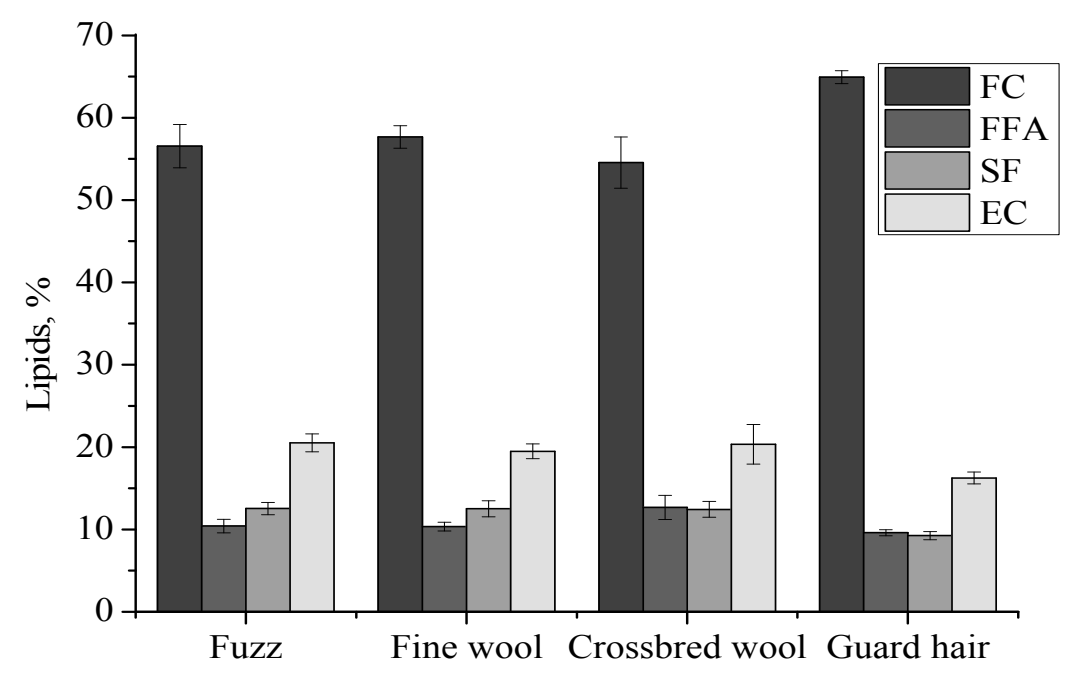

Fig. 2. The composition of free lipids of fuzz, fine wool, crossbred wool and guard hair (the system petroleum ether: diethyl ether, $4: 1, \mathrm{v} / \mathrm{v}$ )

Note: FC — free cholesterol, FFA — unesterified fatty acids, SF — sterol fraction, EC — cholesterol esters

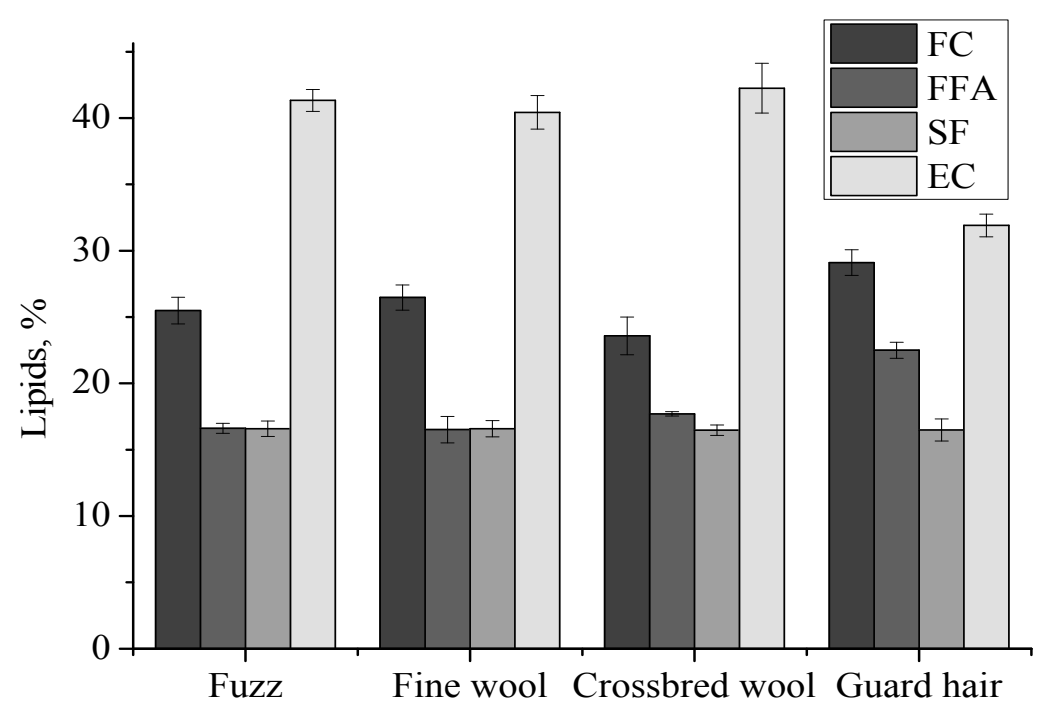

Fig. 3. The composition of covalently bound lipids of fuzz, fine wool, crossbred wool and guard hair (the system petroleum ether: diethyl ether $(4: 1, \mathrm{v} / \mathrm{v})$

Note: FC — free cholesterol, FFA — unesterified fatty acids, SF — sterol fraction, EC — cholesteryl esters 
After analyzing of percentage of each lipid component both free and covalently bound fractions it is possible to observe that whole fiber types have similar lipid distribution. However, major differences related to cholesterol and its esters in guard hair of semi-course wool which are rich in cholesterol, whereas its cholesterol ester content is smaller than in the other fibers. Guard hair is also characterized by the largest amount of free fatty acids. Lipid classes which were separated in the polar system (chloroform-methanol-water, 65:25:4, v/v) are shown in figures 4-5. Free and covalently bound lipids are presented by glycolipids with highest polarity, cholesterol sulfate, glucosyl ceramides, sulfolipids, ceramides and two unidentificated fractions. The results show that the main part of all identified lipids is accounted for ceramides. The content of ceramides varied from $47 \%$ in free internal lipids to $37 \%$ in bound fraction. Similar results were also obtained in other studies $[6,7]$.

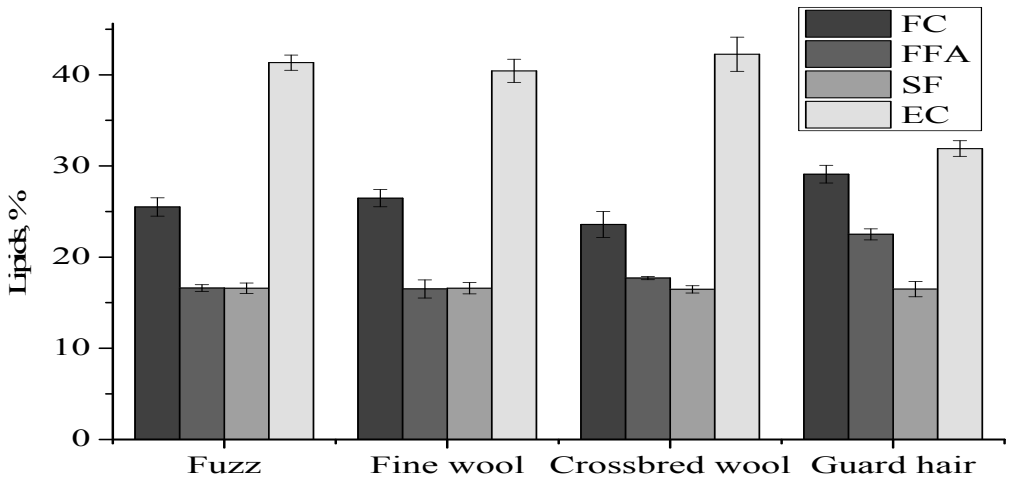

Fig. 4. The composition of free lipids of fuzz, fine wool, crossbred wool and guard hair (the system chloroform:methanol:water $(65: 25: 4, \mathrm{v} / \mathrm{v})$

Note: HPG — highly polar glycolipids, CS — cholesterol sulfate, GCer - glucosylceramides, SL — sulfolipids, Cer — ceramides

There were no significant changes in ceramides content both free and covalently bound lipids. However, literature data show that such factors as ethnic rasa, gender, hair diameter may influence on the ceramides content [7].

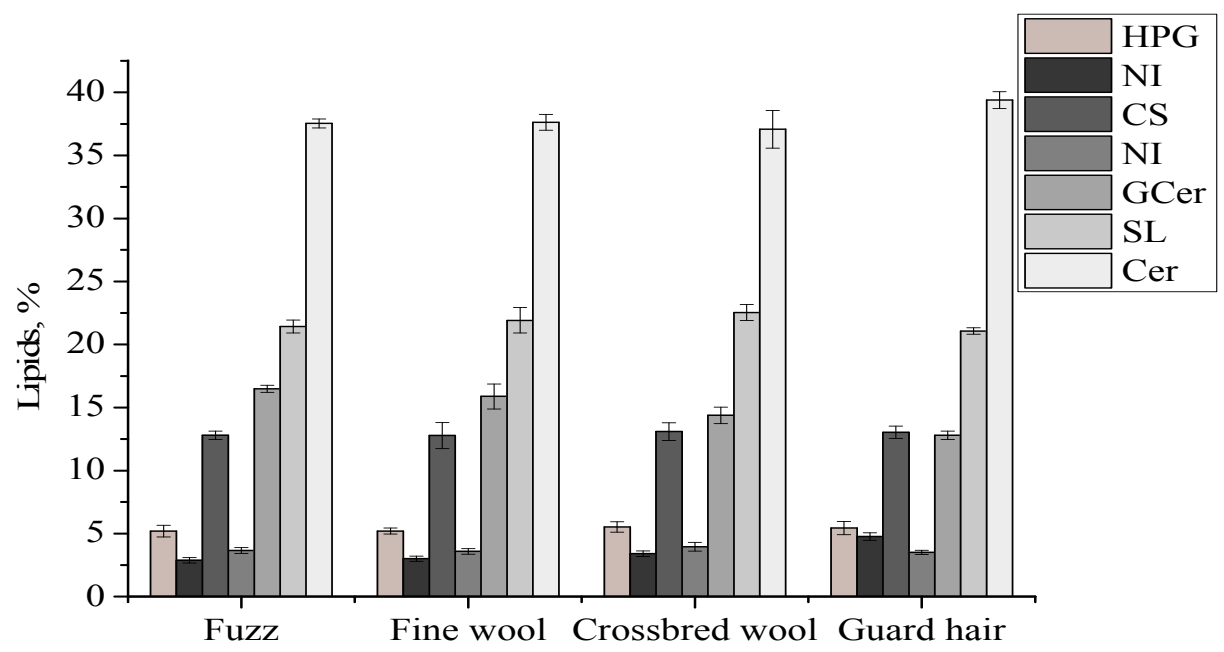

Fig. 5. The composition of covalently bound lipids of fuzz, fine wool, crossbred wool and guard hair (the system chloroform:methanol:water, $65: 25: 4, \mathrm{v} / \mathrm{v}$ )

Note: HPG — highly polar glycolipids, NI — not identified, CS — cholesterol sulfate, GCer — glucosylceramides, SL - sulfolipids, Cer - ceramides 
The polar lipids of keratin fibers contain lipid classes, whose content is characterized by the presence of the sulfur: sulfolipids and cholesterol sulfate. It is known that cholesterol sulfate plays an important role in the cell cohesion during keratinization. These lipids are often called intercellular «cement» of keratinized tissues [9]. The sulfolipids quantitatively prevailed over cholesterol sulfate. However, significant difference in sulfolipids and cholesterol sulfate content in different fibers we have not seen.

The distribution of internal lipids is associated with fiber structure. Free lipids are mainly localized in the cuticle. Perhaps, part of these lipids originates from sebum penetrating the hair shaft and another part of lipids have lost the link with fiber proteins during keratinization [8].

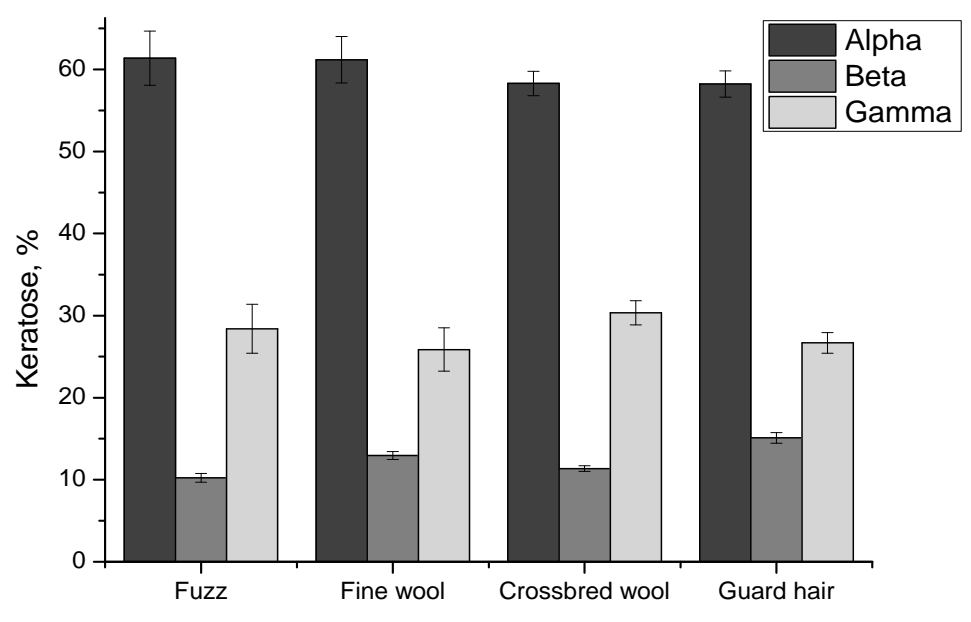

Fig. 6. Keratoses content of wool fibers of different fineness

It is known that $\alpha$-, $\beta$ - and $\gamma$-keratoses are the protein fractions which are derived from oxidized wool and are identified with the fibrillar, cuticle or cell membrane and matrix components of the fiber respectively.

The semi-course wool is characterized by the highest content of $\beta$-keratose $(15.1 \%)$ while the smallest content is observed in fuzz $(10.23 \%)$. The fine and crossbred wool respectively contains $12.95 \%$ and $11.37 \%$.

It is known that coarse wool contains more $\beta$-keratose than fine wool. Actually, this cuticular layer is characterized by the highest content of total lipids [10].

Correlation analysis of the relationship between keratoses content and internal lipids was performed. For the $\alpha$-keratose the data were different in both sign and magnitude. Therefore, these results were ignored.

We found strong correlation between $\beta$-keratose and free lipid content $(\mathrm{r}=0.996$; $0.887 ; 0.698 ; 0.746$ respectively for fuzz, fine, crossbred and semi-course wool). Moreover the inverse correlation between $\beta$-keratose and covalently bound lipid was observed $(\mathrm{r}=$ $0.993 ;-0.995 ;-0.737 ;-0.694$ according to fuzz, fine, crossbred and semi-course wool).

Considering the $\gamma$-keratose and cholesterol sulfate we showed a strong positive correlation for fuzz, fine, crossbred and semicourse wool $(\mathrm{r}=0.341 ; 0.954 ; 0.883 ; 0.996$, respectively), and negative correlation for $\gamma$ keratose and sulfolipids for fine and semicourse fibers $(\mathrm{r}=-0.901 ;-0.999)$. These results confirm the assumption that high sulfur proteins may be associated with lipids, which contain the sulfur.

Interesting results were obtained by analysis of relationship between keratoses and some fractions of covalently bound lipids. The strong positive correlation was observed between $\beta$-keratose and cholesterol sulfate for fuzz, fine, crossbred and semi-course wool fibers $(\mathrm{r}=0.999 ; 0.809 ; 0.342 ; 0.747)$, and a negative correlation for ceramides in fuzz, fine, crossbred and semi-course fibers $(r=$ 
$0.940 ;-0.128 ;-0.895 ;-0.989)$. It was shown the negative relationship between $\gamma$-keratoses and sulfolipids (for fuzz, fine, crossbred and semi-course wool respectively $\mathrm{r}=0.906$; $0.998 ;-0,999)$ and positive correlation between $\alpha$-keratose and ceramides in the all fibers $(\mathrm{r}=0.531 ; 0.572 ; 0.962 ; 0.785)$.

As a result it was found that distribution of structural lipids is closely related to the diameter of wool fiber.

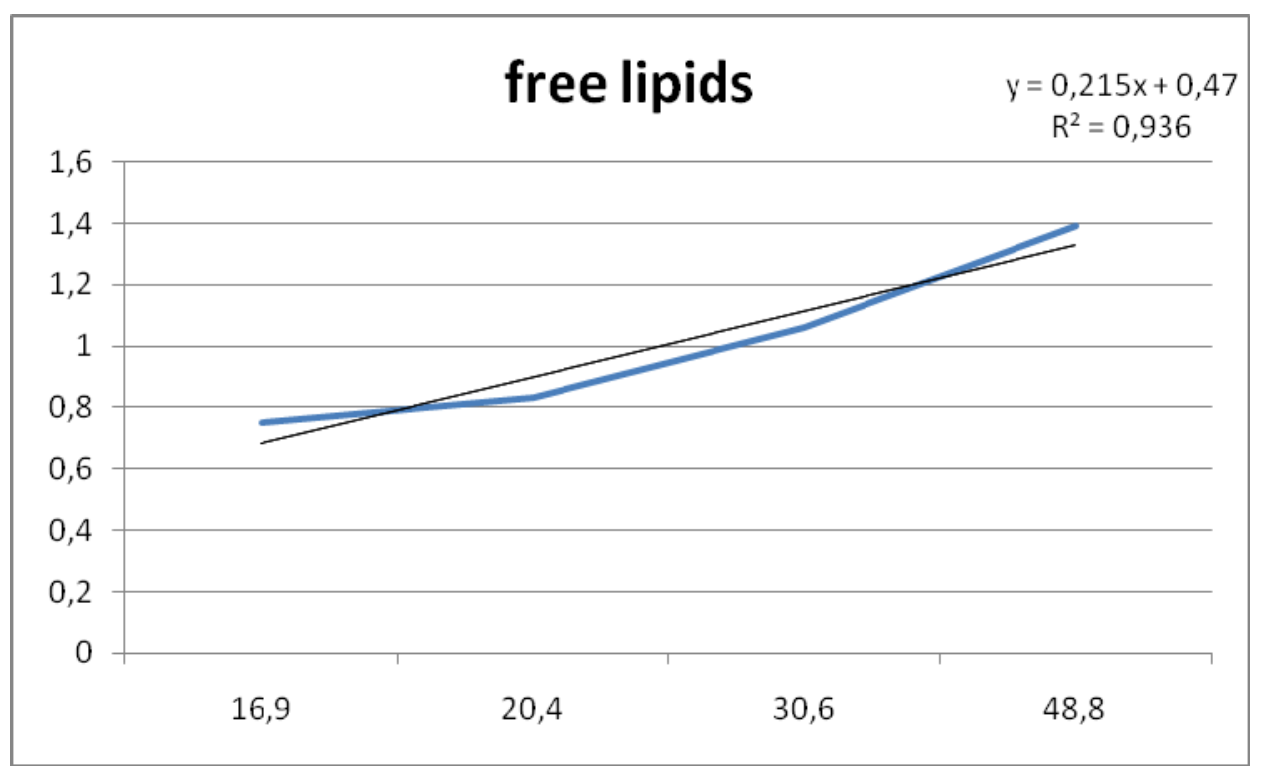

Fig. 7. Relationship between fiber diameter and free lipids content (axis X — fiber diameter, $\mu \mathrm{m}$; axis $\mathrm{Y}$ - free lipids content, \%)

Thus, the content of free lipids increases with the rising of fiber diameter and bound lipids amount, on the contrary, decreases (fig.

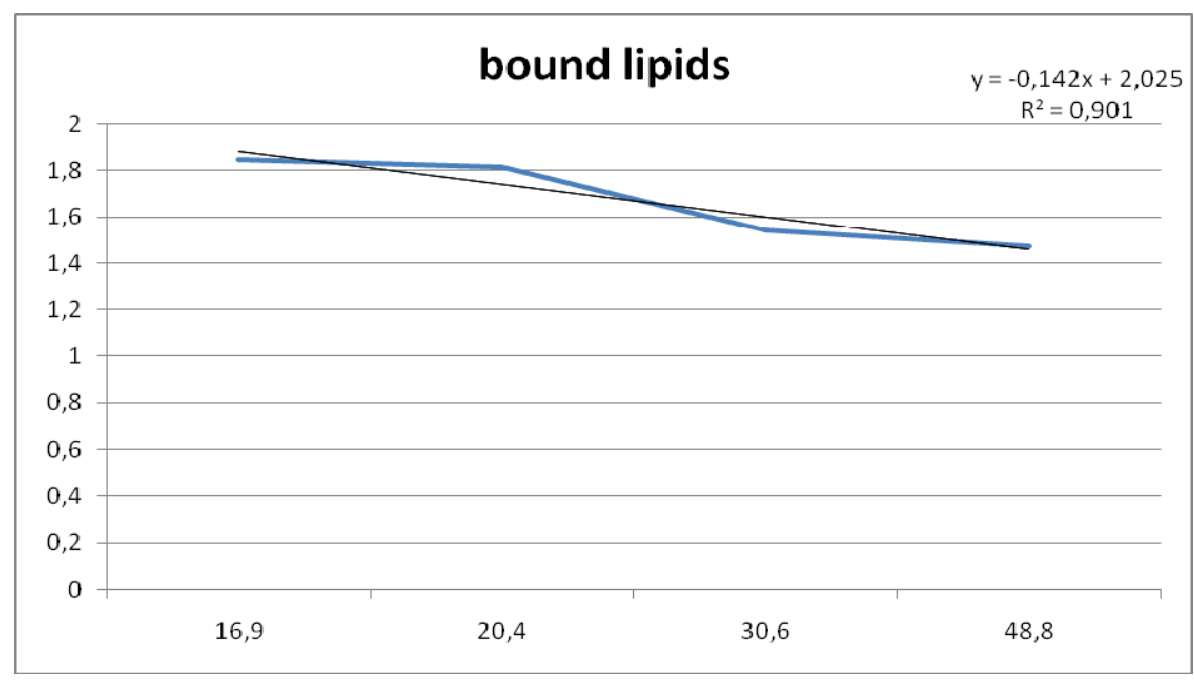

Fig. 8. Relationship between fiber diameter and covalently bound lipids content (axis X - fiber diameter, $\mu \mathrm{m}$; axis Y - covalently bound lipids content, \%)

However, the total amounts of both internal lipid fractions in different fibers are almost identical. The correlations between individual lipid fractions and keratoses in different wool fibers were established. These data give us a better understanding about internal lipids, their composition and distribution among different fibers. 


\section{Conclusion}

It was established that different wool fibers contain various amounts of structural lipids: free internal lipid fraction is rising with increasing of the fiber diameter and opposite dependence for covalently bound lipids is observed. In general, the total content of free and bound lipids in the different fibers is almost identical: thin fuzz contains $2.6 \%$, and fine, crossbred and semi-course wool -2.65 , 2.60 and $2.85 \%$ respectively.

The differences in the structural lipids content are associated with the fiber structure.

It was found a direct relationship between the content of free lipid fraction and fiber diameter $(\mathrm{r}=0.996 ; 0.887 ; 0.698 ; 0.746$, respectively, for fuzz, thin, crossbred and semi-course wool). The inverse relationship for covalently bound lipids was observed ( $\mathrm{r}=$ $0.993 ;-0.995 ;-0.737 ;-0.694)$.

Prospects of further researches. It's advisable to study the content and composition of structural lipids after different treatment of wool fibres.

1. Dyer J., Grosvenor A. Protein Fibre surface modification. In: Dyeing of Textiles with Natural Dyes, Natural Dyes. E. A. Kumbasar (Ed.), 2011: http://www.intechopen.com/books/naturaldyes/dyeing-of-textiles-with-natural-dyes.

2. Mendez S., Manich A. M., Marti M., Parra J. L., Coderch L. Damaged hair retrieval with ceramide-rich liposome. J. Cosmet. Sci., 2011, 62 (6), pp. 565-77.
3. Wertz P. W., Downing D. T. Integral lipids of human hair. Lipids. 1988, 23 (9), pp. 878-881.

4. Wertz P. W., Downing T. D. Integral lipids of mammalian hair. Comparative Biochemistry and Physiology, 1989, Vol. 92 B, № 4, P. 759-761.

5. Asquith R. S., Parkinson D. C. The morphological origin and reactions of some keratin fractures. Textile Research Journal, 1966, 36. pp.1064-1071

6. Wertz P. W. Integral lipids of hair and stratum corneum. Experienta Supplement, 1997, 78, pp. 227-237.

7. Masukawa Y., Narita H., Imokawa G. Characterization of the lipid composition at the proximal root regions of human hair. Intern. J. of Cosmetic Science, 2005, 56, pp. 1-16.

8. Cruz C. F., Fernandes M. M., Gomes A. C., Coderch L., Marti m., Gales L., Azoia N. G., Shimanovych U., Cavaco-Paulo A. Keratins and lipids in ethnic hair. Intern. J. of Cosmetic Sci., 2013, 35, pp. 244-249.

9. Strott C. A., Higashi Y. Cholesterol sulfate in human physiology. What's it all about. $J$. of Lipid Research, 2003, 44, pp. 1268-1278.

10. Stapay P. V., Tkachuk V. M. Strukturni lipidy i zhyrnokyslotnyy sklad keratynu biloyi i pozhovtiloyi vovny [Internal lipids and fatty acids composition of keratin of white and yellowed wool]. Visnyk Lvivskoho natsionalnoho universytetu. Seriya biolohichna - Bulletin of Lviv National Universiry. Biology, 2002, 31, pp. 28-33 (in Ukrainian).

Стаття надійшла до друку 17.06.2013 p. 